\title{
BENGALI MUSLIM WOMEN IN "ZENANA" EDUCATION SYSTEM: A HISTORICAL STUDY IN THE BRITISH PERIOD
}

\author{
Md. Abdullah Al Masum*
}

\begin{abstract}
During the British period, there were different kinds of education system to make the retreated women society of Bengal into a leading class. "Zenana" education is one of its education processes. The word, "Zenana" derives from Persian and means "Harem" or inside the household. So, the education system of those women who live in Harem is called "Zenana" education system. Generally, the introduction of home education for the Bengali women began from the middle ages. But the "Zenana" education is the alternate form of the instruction of concealed women which was different from the existing home education system. This cultural education was initiated by the Christian Missionaries in the earlier part of nineteenth century. Later on, the Hindu society of Bengal also took part in it. But neither the opportunity nor the eagerness of taking Zenana Education continued among the Muslim women for a long time. "Dhaka Muslim Friendship Congress" which was established in 1883 started bringing into practice the "Zenana Education" among Muslim women. Later on the British government began patronizing the Zenana education for the Muslim women alongside the Hindu. The present paper examines the rise and development of Zenana education in the Muslim women society in Bengal from 1883 to 1933 on the basis of contemporary official, demo-official source materials. In addition, this paper will brief the reason of abolition of Zenana education system in 1933.
\end{abstract}

Keywords: Bengal, Muslim women, zenana education, British period

In the $19^{\text {th }}$ Century, the women reform movement in India i.e. Bengal had a main characteristic of spreading female education in the society. It was because education was considered a kind of effective medicine to cure the female society from the diseases of illiteracy, child marriage, divorce, dowry system and above all confinement system and different superstitions; in a word, a treatment for all evil diseases of the society (Sonia, 1996, p.107). But we know that the British Government followed a kind of impartial policy regarding the education system of this country till 1813. ${ }^{1}$ At that time, though the

\footnotetext{
* Md. Abdullah Al Masum, Ph.D., Professor, Department of History, University of Chittagong, Bangladesh

${ }^{1}$ During the second part of the eighteenth century, after taking over the rule of Bengal by the East India Company, the English were quite indifferent for half a century regarding education of people of this country. Moreover, it was considered to be dangerous for the empire and against the interest of the company to give any kind of education to the people of this country. As a commercial organization, the motive of earning more was the only aim. Education Commission: Report by the Bengal Provincial Committee with Evidence taken before the Committee and Memorials Addressed to the Education Commission, Calcutta,: The Superintendent of Government Printing, 1884, p.3. Syed Mahmood, A History of English Education in India, Its Rise
} 
Company Government took part in educational activities on the demand of the Christian Missionaries, the government did not pay any attention to female education. Meanwhile, Adam's report that was submitted to the government in 1835, describes the miserable condition of women in the country; yet, nothing special was mentioned about women education in the education policy of Macaulay, the then Director of public education and initiator of English education. ${ }^{2}$ It can be said that the Company Government was abstained from taking any decision about women education of this country until the Dispatch (1854) of Charles Wood was sent. ${ }^{3}$ Under the circumstances, the movement for modern female education in Bengal as well as in India was organized basically by private initiatives and the Christian Missionaries were in the front line.

Christian Missionaries had landed in this country before the East India Company took over the power in Bengal. But, with respect to the female education, their effort was seen from the last quarter of the $18^{\text {th }}$ century. From that time to the $1^{\text {st }}$ quarter of the $19^{\text {th }}$ century, they founded a number of Girls' Schools. For example, the Missionaries founded a few Girls' Schools in the area of Kiddirpure, Bowbazar in Calcutta till 17821796 where girls of this country studied with the children of the Company officials (Amitab, 1968, p.15; Tapati, 1398, p.228). In 1809, the Missionaries established another Girls' School in Bowbazar, while in 1818, Girls' school was founded in both Zanbazar and Sukias Lane. It is known that Hindu Bengali girls used to study in the School of Sukias Lane. ${ }^{6}$ Within few years 8 (eight) girls' schools were founded in and around Calcutta by the Female juvenile Society, established in the year 1819. Besides these, Schools were founded to spread female education by few other societies including Church Missionary Society, Calcutta Ladies Association, London Missionary Society, and The Ladies Society for Native Education in Calcutta and its Vicinity, Sreerampur Mission (Laird, 1972, p.134; eds. Brogendranath, 1922, pp.36-51). But Missionaries' attempt in this field was not satisfactory. Upper caste Hindu girls along with Muslim girls did not go to these schools founded mainly for preaching Christian religion.

Only the lower caste Hindu and Christian girls of this Country used to study in those Schools. As a result, the Christian Missionaries did not get much co-operation from the nobles or riches and the conservative families of both the Hindu and the Muslim Communities did not send their girls to those schools ignoring "Pardah System." Though momentum for female education was developed in the society due to new rise in the $19^{\text {th }}$ Century, the adult females had restriction to come out of the home. This

Development, Progress, Present Condition and Prospects (1781 to 1893), Aligarh:M. A. O. College, 1895, p.2. Warren Hastings, Memories Relative to the State of India with an Introduction by Anil Chandra Banerjee, First Indian Education, Calcutta: M. L. Ghosh \& Co., 1978 (First Published, 1786), pp. 23-30.

${ }^{2}$ There is no mention of women education in the minute of Macaulay. Please see, T.B. Macaulay, Minutes on Indian Education dated $2^{\text {nd }}$ February, 1835, Calcutta: C.P.O., 1835.

${ }^{3}$ In 1854, first time given importance on modern women education in the dispatch of Charles's Wood, the president of the Board of Control of the East India Company. Please see, Despatch from the Court of Director of The East India Company to the Governor General of India in Council on the subject of the Education of the people of India (No. 49 Dated the 19 $9^{\text {th }}$ July, 1854), Reprint, E.B.\& A.S.P.O. , 1907, p.13.

${ }^{4}$ As Example: We have come to know by the Adam's Report (1838) that in the school of Bardhaman Missionary only 1 Muslim women student out of the total number of 175 students is studying. James Long (ed.), Adam's Reports on Vernacular Education in Bengal and Behar, Submitted to Government in 1835, 1836 and 1838, Calcutta: Home Secretariat Press, 1868, p.216. 
confinement could not be removed even in the beginning of the $20^{\text {th }}$ Century. ${ }^{5}$ The 'pardah' system for girls was considered the worst possible social hindrance for female education. Ignoring this, no appropriate and fruitful way could be identified for spreading female education. Declaring war against confinement or Pardah system could bring no success (Manindranath et.al., 1330, p.82). Besides this, girls were made to leave school after primary education because of child marriage and after marriage they had to stay in the inner part of their house. But comparing to child marriage, Pardah system or confinement was the worst sort of hindrance for female education (General Report, 1906, p.35). To get rid of this condition various thoughts were developed among the missionaries and they started to think deeply and held discussions on how education could be made available to the females staying in the inner part of their house allowing full respect to the confinement System or Pardah system. Thus, they gave birth to a special system of education, "Zenana education". The Missionaries faced financial crisis while delivering institutional education and at that time a huge number of Missionary Schools closed down due to the scarcity of fund (Murshid, 1938, pp.30-32; Sonia, n.d., p.145; Jogesh, n.d. pp.27-29). For this reason "Zenana Education" was introduced to the women as a cheap alternative to the institutional education.

The idea of "Zenana Education" appeared in the mind of the famous Scottish Missionary Alexander Duff (1805-1878). He came to India in 1830 and initiated various programs to spread Western education (Mohar Ali, 1965, p.5). He thought if "Zenana Education" was delivered by women, the Hindu Society would raise no objection. This education would be given early in the first half of the day when the body and mind are active as compared to the evening. According to him there are many matters in the field of education which can be thought only by women (Calcutta Christian Observer, March, 1849). Accordingly, he invited the opinion of Mrs. Wilson (1784- ?) and Krishnamohon Banerjee(1814-1878), the two contemporary pioneers of female education. Both of them advised to arrange for the female education in spite of all the restrictions and problems in the society (Duff, 1855, pp.98-101). On their advice, Alexander Duff started writing in different papers and periodicals to introduce "Zenana Education". As a result, growing interest was seen among some personalities of this area. Under the circumstances, to turn Duff's thought into reality, a Missionary named Mr. Gordais recruited some paid female house tutors in the families of those interested personalities. On the success of this effort, other Missionaries came forward to work for "Zenana education" at personal and organizational level. They selected stitching, drawing, Bengali books on short stories, geography etc. together with the Christian scripture Bible as the course of study for the female under confinement and introduced examination for zenana students and training programme for teachers. ${ }^{6}$ It must be noted that the Missionaries made the preaching of their religion a part of the education.

\footnotetext{
${ }^{5}$ The lady School Inspector has remarked of that time in annual report of the Director of Public Instruction in 1904-05; 'I found from visiting zenana and from the expression of native opinion that there were no prejudice against the education of girls, but strong feelings against any relaxation of the purdah system for high caste girls'. General Report on Public Instruction in Bengal, 1904-05, Calcutta: Bengal Secretariat Book Depot, 1906, p. 28.

${ }^{6}$ Please see in details, Binoy Bushan Roy, Zenana Mission, Calcutta: Modern Colum, 1997, pp. 25-93.
} 
Under the influence of Missionaries' activities, the western education and culture, people, particularly educated Hindu society started to think over "Zenana Education". Iswar Chandra Bidyasagar (1820-1896) and others' effort for institutional education for women was to no avail (Roy, 1998, p.27). On the other hand, entry of Missionary female in home and preaching of Christianity started to create a negative reaction in the fundamentalist Hindus (ed. Ghosh, 1966, pp.523-525, 578-580). Under these circumstances few educationalists and associations of this country took initiative to make "Zenana Education" more acceptable to the society and to spread widely.

In the meantime, we have noted that Krishnamohon Banerjee is the first person among Indian personalities who expressed his opinion in favour of "Zenana Education". In this regard more detailed description is available in a booklet he wrote in the year 1841 . He marked that female education is hindered through open schools. So he requested Hindu gentlemen to extend full-hearted support to establish schools from house to house through foreign ladies. ${ }^{7}$ Though Krishnamohon did not receive a positive response immediately, after some time his thought was reflected in the activities of Keshob Chandra Sen (1838-1884), the leader of Brahmosamaj (1828). In the year 1863 (many say 1862) Keshob Chandra Sen established "Brahmobondhu Shava" the prime object of which was to introduce "Zenana Education."(Roy G. 1938, p.175) Under the initiative of this Association, the course of study, for females confined to their homes, was divided into five classes and textbooks were selected for each class. Their course of study was free from Christianity and fit for a Hindu society. For female students, it was decided that the examination would be conducted twice a year and prize be given according to their merit. It is mentioned in the "Tattiyabodhini(a contemporary periodical)" that within few days of the introduction of examination system, that conference arranged examination for 14 female students (Roy, n.d., pp.33-34). It is mentionable that in producing the textbooks for Brahmobondhu Shava, Umesh Chandra Dutta's "Bamabodhini Shava"(1863) assisted particularly. Besides, the contribution of "Uttarpara Hitkari Shava", established on $5^{\text {th }}$ April 1863, is also worth mentioning for introduction of "Zenana Education." associations like Srihatta Sammilani(1876), Jessor-Khulna Sammilani, Bikrampur Hitasadhinee, Faridpur Surhid Shava etc. came into existence within the next twenty years; the prime object of which was to spread "Zenana Education" in the society. During this time the Government also extended its patronisation of the private organisation's initiative to spread "Zenana Education". In the Report of the Indian Education Commission, formed by the British Government in 1882, "Zenana Education" was termed as an effective method in spreading education among the married and aged females who were not allowed to step out of their homes.

But unfortunately it is true, as the Commission reports, that the social customs of India present enormous challenges for the girls to derive benefits of a school Course---In order to gain the adhesion of public sentiment, it is, they consider, indispensable that

\footnotetext{
${ }^{7}$ Please see in details, Krishna Mohan Banarjee, A Prize on Essay on Native Female Education, Calcutta: Bishop College Press, 1841.

${ }^{8}$ See in details, Bashanthakumar Smantha, Hitakari Sabha Sthrisikhsa O Tathkalin Bangasamaj, Calcutta: Sahithaloke, 1987.
} 
education should in some way be carried into the home, and the effort of Missionary teachers in families willing to receive them is mentioned as having been valuable. ${ }^{9}$

Besides, the Education Commission recommended that the government should recognize and deliver financial support to the Zenana agencies who would conduct secular teaching in the inner portion of the house with the help of skilled teachers.

But all the female education activities of aforesaid associations or the Government were limited to Hindu, Brahman or Christian ladies. No effect of Missionary or Hindu-led Zenana education was seen among the Muslim females. There were some reasons behind it. Firstly, in the education and publications of Christian Missionaries, the religion Islam was attacked openly and Christianity education was compulsory which caused aversion among the Muslim society (Mohar Ali, et.al. 1978, p.122). Secondly, the Brahmasamaj or the section of liberal Hindus conducted their programme of spreading education mainly in their own society. No attention was paid to the education of Muslim society (Ghosh, 2000, p.122). ${ }^{10}$ In addition, during this period, the initiative of education from Muslim leaders such as Nawab Abdul Latif (1828-1893) was limited to the male members of the society. There is no evidence to say that Nawab Abdul Latif had the thought of educating females, though Adams' reports (1835-1838) tell about the home education of the females in the aristocrat Muslim families (Long, n.d., pp.132133). However, it is known that, Muslim leaders did not introduce any effective home education for females under confinement as an alternative to the institutional education. ${ }^{11}$

Under the circumstances, some educated youth of East Bengal founded "Dhaka Muslim Surid Sammilani" on $24^{\text {th }}$ February 1883 , and started a joint venture for education of Muslim females like "Zenana Education". This society or association was constituted selecting Moulavi Himmat Ali as the president and Moulavi Abdul Majid as the Secretary. Among the members of the working committee of this association were Hemayet Uddin(Later Khan Bahadur), Zuhadar Rahim(Later Justice Zhedur Rahim), Mokbul Ahammad, Azad Ali, Modachcher Hossain, Syed Hazarat Ali, Mohammad Fazal, Moulavi Nawjesh Ali, and Moulavi Mohammad Sadeq. Besides, some more youths like Abdul Karim (Later School Inspector), Abdul Aziz (Later Khan Bahadur), and Abdur Rahman(Later Khan Bahadur) were the zealous workers of the association

\footnotetext{
${ }^{9}$ Report of the Indian Education Commission, 1882, Calcutta: The Superintendent of Government Printing, 1883, pp. 535-36, 549.

${ }^{10}$ Binoy Ghosh said, "But it does not mean that the Young Bengal or Brahammah Samaj had communal mentality or anti Muslim. Real historical fact, however, the rise and development of Hindu middle class."Please see, Ibid.

${ }^{11}$ The attitude of Nawab Abdul Latif, the contemporary leader of Muslim community and educationist regarding female education is available in the minutes of the meeting of 1868 of Bengal Social Science Association. On hearing the article read by Nawab Abdul Latif, edited by Muslim Education, Pyarichand Mitra (1814-1883) asked a question to know that whether any step was taken for female education in Muslim Society Similar to that of for Hindu Society. In reply to his question most probably Nawab Abdul Latif did not give any reply. But Abdul Hakim, Teacher of Calcutta Madrasah, on invite in the meeting mentioned the necessity of home education for the Muslim girls because of pardah System. But nothing was mentioned in the minutes whether he had said any kind of home education in the light of "Zenana Education." Abdul Latif "A Paper on Muhammadan Education in Bengal", Transaction of the Bengal Social Science Association, Vol. II, Part 1, Calcutta, 1868, pp. 60-64.
} 
(DMFA, 1884, pp.-14). After few years, Abdul Aziz, one of the workers, became the secretary of this association (DMFA, 1888, p.16). From the first record of this association it is known that, in the beginning, the activities of this organization were limited to spreading female education. In this respect it is said that "The grand object of this association is to work for betterment of Muslim of Bengal. For the time being this organization shall be devoted to spread female education in the Muslim Society of this country."(DMFA, 1888, pp.-5-6) But this system of spreading of education was not organizational. Considering the difficulties in establishing girls' schools or institutional education for girls practicing purdah, this association made the curriculum and textbooks for home education. This education system was limited from class one to class five and the courses of study and textbooks were fixed by the association. Arrangement was there to conduct annual examination in each of the classes. Students had to get prepared on the basis of the courses of study fixed by the association and the examiner had to go to the students' home to set the examination with the help of the local guardians. According to the annual statement of the association, "Any Muslim female residing in Bengal who desire to sit in the examination as per rule based on the selected textbooks can appear in the examination. The ladies can appear in the examination in their own home under the supervision of their own guardians."(DMFA, 1888, pp.-9-10) In the beginning the examiners arranged to conduct examination in two languages, Urdu and Bengali. After a few years examination was conducted through a mixed medium of Urdu and Bengali and the stage of education extended up to class VI. (DMFA, 1888, pp.-9-10) In 1883, in the $1^{\text {st }}$ year of the Association's foundation, total 37 examinees from Dhaka, Barisal, Noakhali, Moimonsingh and Calcutta appeared in the examination and out of the total number, 34 students passed and all of them were Muslims. In that year along with Abdul Karim (Calcutta), Emdad Ali (Calcutta), Noajesh Ali (Mymensingh) Faez Uddin (Barisal), some persons observed the responsibility of the examination as caretaker and examiner. Certificates and awards were given to the successful candidates on behalf of the association. (DMFA, 1884, pp.11-18) Without being associated with any school, this system of Zenana Education was completely free and independent. The members of Suridh Sammilani (Association) understood the deep relation of female education and freedom of female with the rise and advancement of society and on being so they made this arrangement within their capacity. Undoubtedly, their effort was noble though that was little compared with the vast Muslim female society of Bengal. A contemporary litterateur, Nawser Ali Khan Usufji (1864-1924) appreciated the activities of Suridh Sammilani and considered the result of their initiative to spread female education as highly satisfactory as Muslim girls of different districts passed the examination they organised. He was of the view that Suridh Sammilani would be successful in giving great benefit to the society if the help of common people is extended to them Yousufjee, 1890, pp.43-44). But this arrangement of Dhaka Sammilani was for a brief period and was limited. After the year 1905, the existence of this organization could not be traced (Abul Kaium, 1348, pp.20-21).

The participation of Muslim female in the examination of "Zenana Education" organised by Srihattah Sammilani in the year 1884, the following year of the foundation of Dhaka Surhid Sammilani, is also evident. Srihattah Sammilani was founded in the year 1876 with the aim to establish unity and affection only among the youth of Srihattah residing at Calcutta. In the course of time, the concentration of the association 
was attracted to the female education for the welfare of all the residents of Srihattah and the development of women. Though the Srihattah Sammilani was founded under the leadership of Hindu namely Bipin Chandra Paul, Anandamohon Das, Sundarimohon Das, Tarakishor Chowdhury etc, later, Muslim leadership also became the patron of this organisation. Sirajul Islam (1884-1923), Abdul Karim (1863-1943), Moulovi Ahammad Ullah were members of Srihattah Sammilani and a few school were founded in the city of Srihattah under the initiative of the Sammilani for female education of the both communities, Hindu and Muslim (Sundari, 1388, pp.1-2). But there were no obligations on the part of the Sammilani regarding school education. The females of inner part of house (Andarmahal) were also allowed to take part in the examination according to the course of study selected by the Sammilani. The students used to submit their application one month before taking the examination. In the year 1883, the last date of submitting application was $15^{\text {th }}$ December. But the examination was held in the month of January 1884. The number of applications submitted was 375 but only 181 women appeared in the examination of Srihattah Sammilani. Out of these students, 22 were Muslims. The students had the opportunity to use both the languages Bengali and Urdu in the examination. Among the Muslim examinees, ten (10) students chose Urdu and the other 12 students chose Bengali medium. Out of these 22 Muslim women, 10 were successful. Among the Urdu medium examinees, 4 students secured first division. During the subsequent years the number of participants in Zenana examination increased. In the year 1889, total 611 women appeared in the examination of Sammilani. Out of them, 528 candidates became successful. Among these successful examinees, 74 students were Muslim. An Award along with a certificate was given to the successful examinees. In the year 1889, Shirajul Islam, Advocate of Calcutta High Court declared an award valued at Rs.10/- in the annual prize distribution ceremony of Sammilani to give an impetus to the education of Muslim females. In the same year, a special award was given to Chartunnesa Khatun for her extraordinary skill in Zenana Education. During subsequent years, it is evident from statistics that, about 100 Muslim women became successful in the examination of Srihattah Sammilani every year. Generally, the 4-yearold child to the 35-year-old female students could get the chance to appear in the examination. But in some of the years, female of 45 years age appeared in the examination (Maya, 26 ${ }^{\text {th }}$ Year, pp.44-45). ${ }^{38}$ It is also known that Muslim females took part in the programme of Zenana Education initiated by Tripura Home Female education Commission, founded in Dhaka in the year 1871. Kailash Chandra Nandi and Kailash Chandra Dutta were the President and Secretary of the organisation respectively. At the same time, a similar organisation was founded in Comilla and few years later, the organisations of Dhaka and Comilla took a resolution to conduct "Zenana Education" jointly. No Muslim women were seen taking part in the examinations held within the first decade after the foundation of the organisation. In the year 1883, a number of 98 women passed in "Zenana Education" and out of them 8 women were Muslim and the rest were from Hindu Community. All the Muslim women were residents of Comilla and Beshlata area (ZWE, 1291; Roy, pp.82-87). Thus, in the last quarter of the $19^{\text {th }}$ century, participation of the Muslim women in "Zenana Education", privately ventured, started to increase gradually. From the statistics of census report of 1901, it is known that 400 Muslim women learned English under the arrangement of "Zenana Education" of Bengal (Cencus of India, 1901, p.61). Under the circumstances, a proposal was given 
to establish educational institution for Muslim girls. At that time the matter of learning English by 400 Muslim females as per census report was described as an unbelievable incident in an article published in Mihir \& Sudhakar. Besides, it was also said that if the Muslim women can learn English through Zenana system then there would be no objection in giving education to the girls through Schools (Mihir et.al. 1977, p.22). But it was not so easy to impart education to Muslim female through establishing school in the contemporary conservative Muslim Society. Though there was no such restriction for the Muslim girls to go to school for primary education, their participation in secondary education was almost nil. It is evident from the statistics of that time. In the five year report (1902-1907) of the Government it was stated that only 23 Muslim students were obtaining secondary education. In this respect it was mentioned in the educational report, where the ratio of Hindu male and female students at primary and secondary level was 30/1, that of Muslim male and female students was 68:1 (Progress of Education in Bengal, 1908, p.128). The Pardah system of society was a major cause behind it. We have seen in the aforesaid education statistics that the Muslim society was much more conservative as compared to the neighbouring Hindu society. In the description of the contemporary school inspector Miss Brook, support to this opinion is available (GRPIB, n.d. p.35).

In this situation the British Government realized the importance of imparting "Zenana Education" for grown up Muslim women in 'pardha'. Though the Government had been cooperating in different ways with the venture of "Zenana Education" by the Hindu Society since the $19^{\text {th }}$ century, no such effort was seen for the Muslim female (EARUHS, 1872, p.12). But, when the "Zenana Education" for Muslim females was initiated and the institutional education had not been successful because of the confinement system, the Government paid attention to the female education under confinement.

In the last decade of the $19^{\text {th }}$ century, Government's desire for "Zenana Education" of Muslims was reflected officially in the statement of Alexander Peddler, the then Director of public education. He stated various objections of Muslim females along with different problems of Hindu society in "Zenana Education". In this regard in a letter to the Secretary of Bengal Government he informed that the influence of Christian Missionaries was the prime hindrance to the system of "Zenana Education". If secular education could be introduced removing the fear of conversion to Christianity from the mind of both the communities, Hindu and Muslim, then, the number of female students in the Government Schools would increase and the spread of "Zenana Education" would be accelerated. For this reason, he recommended the Bengal Government to introduce "Zenana Education" through indigenous Hindu or Muslim women rather than Christian women. All these home teachers would assemble students from the houses around in a house of any influential Hindu or Muslim person and impart education. A committee comprising people of both the communities, proportionate to the population of the regional communities, would take the responsibility of appointing house tutors for Zenana Center and guiding them. Besides this, Peddler also proposed to impart education to the females by going from door to door. He proposed to conduct "Zenana Education" of the same kind in Calcutta, Pabna, Burdown, Dhaka and Kattak as a test case. Then, the Government implemented this proposal and appointed 8 lady teachers to 
impart education in central gathering. Besides 68 lady teachers were appointed to impart education from house to house. As a result a number of 1430 female students from both the communities, Hindu and Muslim, got educated under that system (GRPIB, 1896, pp.90-130). In the aforesaid statistics, separate number of Hindu and Muslim women could not be traced but it could be guessed that the number of Hindu female students exceeded Muslim female students.

So, in the beginning of the $20^{\text {th }}$ century, the Government arranged some programs to create more desire in the Muslim females for "Zenana Education". On the other hand, during this time, recommendation was made to the Government to give more importance towards "Zenana Education" in the Shimla Education Convention held in the year 1901. The Bengal Government organized an Education Convention at Calcutta on $9^{\text {th }} \& 10^{\text {th }}$ March 1903, aiming to increase "Zenana Education" in Muslim Society and to implement proposal of Shimla Convention. In that convention, course of study to be followed in "Zenana Education" system, suitable for Muslim females, was prepared. Here, according to the recommendation of Alexander Peddler, two types of former Zenana Education system continued. Moreover, eight Muslim lady teachers were recruited to impart "Zenana Education" particularly to Muslim females and their monthly salary was fixed at Rs.30/- (GRPIB, 1904, pp.124-127). Prior to this, the Government formed a committee to fix the policy regarding the "Zenana Education". Under the presidency of Roybahadur Radhanath Roy, School Inspector of Burdwan Division, Moulovi Mohammad Ibrahim and Moulovi Abdul Karim, Muslim School Inspector of Chattagram and Dhaka Divisions respectively, were appointed as members of this committee. In the Education Convention of Calcutta, recommendations of this committee were placed. Regarding Muslim "Zenana Education", the proposals of the committee were: 1) to spread "Zenana Education" in the villages where Muslims are majority, a committee is to be formed comprising of two members, both of who must be from the Muslim leadership of the area. The activities of this committee shall be to select competent teachers for "Zenana Education", to select appropriate place for the students, and to supervise the expenditure and all other activities; 2) the Government is to bear the expenditure for an attendant to the teacher, book, slate and papers according to the necessity of the teacher; 3 ) to arrange for awards of different kinds including cash money for the students according to their presence and merit. In addition to this, Roybahadur Committee recommended including the teaching of Home Economics, simple Maths, Health Education, Childcare etc along with important subjects in the course of study. It was also said that no male inspector could inspect the centre or class. Considering all the proposals of Roybahadur Committee, Calcutta Education Committee resolved to implement those in all the districts of Dhaka, Chittagong and Burdowan Division and in the Districts of Nadia and Murshidabad of Presidency Division (GDEP, 1904, 37-38). But due to the want of competent Hindu and Muslim teachers and lack of routine inspection, implementation of that project suffered a great deal.

In this situation, the female inspector Brook proposed to employ one experienced teacher from each Hindu and Muslim society in the main cities of each Division to meet the demand of female teachers. At this decision of the government, the demand of the female teachers increased. But skilled teachers were not sufficient regarding the demand. Through examination it was proved that the teachers were unable to write 
simple letter in their own language; they were weak in mathematics and their knowledge of stitching was poor. So, in reality, challenges were there on the way to spread "Zenana Education." (PEB, 1902-07, pp.127-28)

With this difficulties and hindrances toward Zenana i.e. female education in Muslim society of Bengal, Muslim leaders assembled in a meeting in the department of the Director of Public Instruction on 1st March, 1907. Total 17 Muslim leaders attended the meeting, including Mirza Sujat Ali Beg (1860- ?), Syed Amir Hossain (1843-192-14 ?), Mohammad Azizul Haq (1892-1847), Moulavi Mohammaed Ebrahim. During the discussions in the meeting, the Muslim leaders basically gave importance to the selection of appropriate course of study for spreading "Zenana Education" in the society. In this regard, a subcommittee of 7 members was constituted making Mirza Sujat Ali Beg, the president. This sub-committee selected a special course of study for Muslim "Zenana Education". The main subjects of this were History, Geography, Mathematics, Drawing, Stitching, Health Education and Home Economics, Religious Studies, Drill etc (GDEP, 1907, pp.6-10). After proper appraisal, the Government ordered to implement the aforesaid proposals regarding the course of study.

In the Education Conference of 1907 recommendations were made to appoint required number of Muslim lady teachers everywhere in Bengal for "Zenana Education". As a result, in the month of August of that year the Government appointed 6 teachers in Patna of Behar to spread Muslim "Zenana Education". The monthly salary for the lady teachers was fixed at Rs. 5/- and one female was recruited for supervising (GRPIB \& GDEP, 1908, pp.31-35 \& pp.124-127). At this time the "Zenana Education" system was divided by the Government into three types. 1) Education by the lady teacher going house to house; 2) imparting education by confined lady teacher at their own home 3) a few centres set to provide education. At that time the Muslim lady teachers preferred teaching in their own houses. In 1909-10, another group of 6 Muslim lady teachers was recruited to teach "Zenana Education" and their monthly salary was fixed at Rs. 5/-. Here, it is to be mentioned that the salary of the lady teachers other than the Muslim lady teachers was Rs. 30/- per month. The salary of Muslim lady teachers was much less as compared to that of others. As per reference of the Government this discrimination of salary was due to less capability of Muslim lady teachers and appointment of additional lady supervisor for them (GRPIB, 1910, p.38). With various Government initiatives, "Zenana Education" was extended in West Bengal in the 1st decade of the $20^{\text {th }}$ century. In the education report of the Government it is seen that in 1910, 251 students were studying under 12 Muslim lady teachers in West Bengal. Moreover, under the Zenana centre, 206 students were engaged; while 834 students were getting educated under the system of door to door teaching. Though separate communal statistics on the advancement of the aforesaid two systems were not known but it is true that the number of Muslim students was not mentionable. In these two systems, Hindu, Christian or Brahma teachers were engaged and their educational activity was conducted in the West Bengal area where Hindus were the majority. On the other hand Muslim teachers were engaged in the area of Patina of Behar. It is also worth mentioning that in the field of education the Muslim females of this area were more interested compared to the females of other areas of West Bengal (GRPIB, 1911, p.17). 
On the other hand, after partition of Bengal in 1905, with different schemes made for "Zenana Education" in East Bengal, the participation of Muslim female was observed. A Conference of Director of Public Instruction and lady inspectors was held in Dhaka on $21^{\text {st }}$ January 1907, aiming to spread "Zenana Education". It was decided in the conference that "Zenana Education" should be made available to the common people. For this purpose, it was decided that no school would be established rather it would be family assembly. This education would be imparted in those areas where females are not being educated. Besides, this education should be appropriate and helpful to those widows who had none to take care of (Molla, 1981, pp.210-11). With this aim, five separate lady teachers; one for English and four for native languages were engaged for "Zenana Education" in Dhaka. English teacher took the charge of English language and Stitching. Among the teachers of vernacular, two were Muslim, One Christian and the other Brahma. Each of the teachers used to impart education in six centres. The two Muslim teachers were working only with the Muslim females; Brahma teacher taught Hindu family and Christian teacher imparted education to the girls from both the families, Hindu and Muslim. The teachers were receiving a salary of Rs 50/- per month (PEEBA, 1913, p.86, 101). A committee was formed under the leadership of educated women in the month of June, 1910, to fix the direction of "Zenana Education." Meetings of this committee were held at different places and discussion continued on the challenges and advancement of "Zenana Education." Because of the sincere efforts of the teachers, "Zenana Education" of Dhaka improved. In the year 1906-07, there were 21 Hindu and 17 Muslim students in the Zenana centres of Dhaka. In the year 1911-12 the number increased, the number of Hindu women increased to 126 and Muslim to 149(PEEBA, 1911-12, p101). Therefore, it is evident that in "Zenana Education" of Dhaka, Muslim females did better than Hindu females.

In Gopalgonj of East Bengal, the classes of Zenana were conducted under four lady teachers. They taught writing, reading, Mathematics and Stitching in nine centres for five days per week. More students were gathered from the farmer families whose age varied from 13 to 40 years. In the year 1911-123, the number of increased to 68, out of which 44 students were Hindus, 16 Muslims and 8 Christian. Earlier "Zenana Education" was discouraged in the districts of Comilla, Chittagong and Noakhali of Chittagong Division. However, in Comilla, one lady teacher used to conduct classes in six centres for two days a week; she had 43 students, out of which 33 were Muslim and 10 were Hindus. So, it is to be noted that like Dhaka, Muslim students were more in number than Hindus in Comilla. The salary of the teachers of Comilla was fixed at Rs.45/- per month. At that time, classes in Noakhali were suspended due to the death of a Zenana teacher. In the month of March, 1911, when the class was reopened this education advanced gradually. In Noakhali among 38 students, 7 were Muslims. In Chittagong six Zenana centers were there under one lady teacher. But, all of the 36 students there were from the Hindu Community (PEEBA, 1911-12, p101-2).

In Bogra and Jalpaiguri of Rajshahi Division, Zenana classes started under the supervision of Women Committee. There were two lady teachers in Bogra, one of them was receiving Rs. 50/- per month and the other Rs. 45/- as their salary. Additionally both of them used to receive Rs.20/- as allowance. In Bogra there were five Zenana centres and out of 91 students, 47 were Hindu and 44 Muslim. In Jalpaiguri five Zenana centres 
were there under one lady teacher. She used to receive Rs. 40/- per Month salary and Rs. 20/- as additional allowance. Under her guidance, there were 48 students out of which five were Muslim and 43 Hindu students (PEEBA, 1911-12, p101-2). During the period of movement against partition of Bengal (1905-1911) the success of "Zenana Education" of East Bengal produced interest in people of Assam to establish Zenana Centre. Before that, there were no Zenana Centres. The people of Shibsagar and Silchar requested the Government to introduce "Zenana Education". On their demand, 6 centres were opened in Silchar and in thse centres there were 100 students from both the communities, Hindu and Muslim (FECEBA, 1911, pp.96-97). In all these centres, course of study was Health Education, Domestic Science, Sewing etc(PEEBA, 1908-12, p.102).

After the withdrawal of Bengal partition in 1911, there was a great difference between the education of East and West Bengal. For this reason the Government started new thinking on female education. The prime object of this was to introduce a new policy of female education through accepting the good aspects of both the parts based on the past experiences. With this aim, a committee was formed comprising 23 members, out of which 17 were female, under the presidency of Robert Nathan, Education Officer of the Government. Among the Muslim male members, Nawab Ali Chowdhury (1863-1929), Khan Bahadur Ahsan Ullah (1873-1963), the education inspector of Chittagong Division, were attached to that committee. Regarding "Zenana Education", this committee had a number of proposals. In this context it can be said that a great difference was there between the "Zenana Education" of West and East Bengal. The system of imparting education by assembling in small groups at a house of some persons was not successful in West Bengal. So the system of door to door education was in vogue there. To impart education to Muslim women of different areas of Calcutta, there were four lady teachers and four suburbs, so 14 lady teachers were employed. But in spite of this, the result was not up to the mark and hence appointment of one Government female inspector was proposed. The Committee believed that Muslim "Zenana Education" would be expanded if the aforesaid proposal was implemented. Nawab Ali Chowdhury, member of the committee, recommended imparting education by establishing centre for women to spread Muslim "Zenana Education" in Calcutta. In this regard he referred to the success of Muslim female of East Bengal. So the Nathan committee proposed to establish two more Zenana centres in Faridpur and Mymensingh to achieve more success in this field (GDEP, 1915).

Along with the Nathan Committee, the Muslim Education Advisory Committee, constituted in the year 1914, also gave importance to female education of the society. After investigation at different levels and taking the statement and recommendations of Muslim leaders, the Education Committee said that the subject of Muslim female education is marked to be a great problem in the society. Despite various plans by the Government, according to Shimla Conference of 1901 and Calcutta Conference of 1907, few of them were materialized. Therefore, along with other proposals to solve the problems of Muslim female society, the Advisory Committee submitted proposals for "Zenana Education" too. In this regard it was said that in the field of "Zenana Education" in Calcutta the number of Muslim lady teachers and Zenana centres must be increased. Arrangement should be made to introduce proper course of study for them, 
printed books to be distributed and for the successful students' arrangement of certificates should also be made. The Committee also recommended establishing training School-College to train Muslim lady teachers. ${ }^{12}$ Moreover, Calcutta University Commission, constituted by the British India Government in 1917, said that although Zanana education system was appreciated in the Muslim society there were so many problems regarding Muslim lady teachers. Commission recommended that Government should give importance to this education system and arrange higher education for the female students who are interested to progress in their studies (CUC, 1920, pp.166-8; 165-69).

So, it is to be noted that all the contemporary committees and commissions gave importance on "Zenana Education" of Muslim females. In this respect Bengal Government founded Zenana Centre in different places of the country, appointed lady teachers, and granted funding. In Faridpur, "Zenana Education" activity started in the month of June, 1913, through the establishment of 6 centres. Out of those centres, two were marked for Muslims and 4 centres for Hindus. At that time there were 8 Muslim and 20 Hindu students in the Zenana centres. In Madaripur, six Zenana centres were established. Out of aforesaid 6 centres, 2 were for Muslim and 4 centres were for Hindus. But in all these centres no significant success was seen in Muslim "Zenana Education". The impetus, which developed, initially, in the Muslim female was shattered when financial grant for the reward to the students ceased by the Government. Education of the married women was disturbed due to their frequent movement between the houses of father and father-in-law. Besides, the students were more interested in learning sewing rather than any other general education. In spite of all these problems it was mentioned in the Government's report that enthusiasm originated among the Muslim women for "Zenana Education" in Madaripore (QRPED, 1918, pp.11-12). In the year 1914-15, six more Zenana centres were established in Rangpur and Pabna where students from both the communities, Muslim and Hindu, had the opportunity to study. In East Bengal, the centres situated in the residence of Zenana lady teachers were known as Home School and the Government allocated a grant of Rs. 10/- for each of the school (GRPIB, 1916 \& 1918, p.14 \& pp.110-11).

The activity of "Zenana Education" started in Mymensingh in the year 1917-1918 under a Zenana lady teacher. Two centres were established here for Muslim students. Similarly, Zenana centre was established in Barisal during the same period. But within a very short time the centres of Barisal and Mymensingh were closed down due to want of interest of local people. In one of the centres of Mymensingh, Muslim females achieved expected result in examination of sewing craft. But Mathematics was a problematic subject for them. In the year 1917-18, three centres were established in Comilla for females of both the communities, Hindu and Muslim. There, interest for English was seen among the females. But due to lack of lady teachers, the centres had to be closed. Under these circumstances, the Government appointed a teacher of Faizunnesha Girls School as Governess in Comilla (PFED, 1920, p.10; 1921, pp.10-11).

\footnotetext{
${ }^{12}$ Report of the Committee Appointed by the Bengal Government to Consider Question Connected with Muhammadan Education, Calcutta: Bengal Secretariat Book Depot, 1915, p.38-41.
} 
In the year 1918 there were six Zenana lady teachers who used to impart education in 12 Muslim centres. In our earlier discussions we have noted that "Zenana Education" created interest in the Muslim Society of Dhaka District and city. But due to want of Urdu teacher, problem in "Zenana Education" of Muslim female was in existence.

During the period Bengal Government extended additional grant for "Zenana Education". For example, in the year 1914-15, the Government sanctioned additional grant of Rs. 5,400/- to spread "Zenana Education" in Presidency and Burdowan Division. With that amount, 5 additional teachers were appointed in Calcutta, 5 in Presidency Division and another 5 in Burdowan Division. Out of those, five teachers of Calcutta were imparting education only to the Muslim females (PEP \& B, 1918, pp.8-9). At this time (1915-16) the number of lady teachers of Zenana System of whole Bengal increased to 74. Muslim lady teachers guided 10 centres out of 33 centres of West Bengal (PIB, 1922, p.15). In the year 1914-15 the Government arranged training for the lady teachers, under confinement, in Dhaka. On the other hand, during this time the Zenana course of study was revised to make it more useful for female education in West Bengal (PIB, 194, p.21). Under all these arrangements made by the Government, during the second decade of $20^{\text {th }}$ century, "Zenana Education" achieved its popularity among the females of both the communities, Hindu and Muslim, despite different types of hindrances. For example, in the year 1912-13, there were 1277 students in "Zenana Education" which increased to 1737 in the year 1916-17 (PEB, 1914, p.21). In the Government report of "Zenana Education" no separate figures for Hindus and Muslims are available. But we have noted that in the very beginning of the $20^{\text {th }}$ Century, Muslim females started to take part in "Zenana Education" and the Government introduced separate arrangement for them in both parts of Bengal. So, in that statistics of "Zenana Education" participation of Muslim female was at a mentionable rate: "In West Bengal, Zenana teaching for Muhammad an is steadily improving and centres at Margram and Murshidabad are making great progress." (PIB, 1914, p.21) Besides, from another document it is clear that in 1916-17, under the Government of Bengal, a number of 598 Zenana students were studying in the divisions of Rajshahi, Dhaka and Chittagong. Therefore, in perspective of new rise in these areas, where Muslims were majority, the role of female of that community was great in "Zenana Education". Regarding this Miss Bose, female inspector of education department said:

The system of education, by means of house-to-house visitation and in central gatherings, is a great boon to purdah women, both Hindu and Muhammadan, and is very highly appreciated by people of both communities (PEB, 1912-16, pp.110-11).

In spite of advancement of Muslim society in "Zenana Education", various problems were still there in the way of its spread and control. Among those problems, lack of competent lady teachers, insufficient grant and different drawbacks in the system of "Zenana Education" etc are mentionable. Because of all these kinds of hindrances, system of "Zenana Education" had to be restricted, though three kinds of "Zenana Education" were implemented in West Bengal. For example, the system of "Zenana Education" (Atus system) in the residence of Muslim teachers which was in vogue in West Bengal in the beginning of the $20^{\text {th }}$ Century was closed after prevention of the Partition of Bengal. In the year 1912-13, two more Zenana centres were closed due to 
want of required finance and lady teachers (PIB, 1912-13, p.21). The want of competent lady teacher was the main hindrance of "Zenana Education" which was mentioned repeatedly in the contemporary education reports of the Government. Most of the teachers used to impart education of primary standard to the students. As the salary of Muslim lady teachers was poor, the post was not attractive. But it was also uncertain to get qualified teachers with good salary. Besides, the teachers had poor knowledge in Urdu; hence, they used to impart education in Bengali which caused problem for Urdu speaking people. On the other hand, problem was there in imparting education visiting house to house by the lady teachers. In East Bengal, during monsoon, along with the problem of transport, want of financial assistance and wastage of time were the major hindrances. Lady teachers did not even get money accordingly. In imparting education by going house-to-house many female faced various problems and left the post of teacher. ${ }^{13}$ Besides, because of strict Pardah System, females did not like to go to others' residence or Zenana Centres for study. In case of married women this education used to be disturbed; because they had to look after their child and they used to move intermittently between the houses of their father and father-in-law. The course of study of "Zenana Education" was not appropriate for the society and there was a crisis in supply of equipment (EPBD, 1929, p.9; PEP \& BD, 1920, pp.14-5). Owing to all these hindrances, the number of students and teachers of "Zenana Education" started declining from the year 1917. In the education report of 1920-21, it was seen that the number of students studying was 1399 under 59 teachers in "Zenana Education." (PEB, 1920, p.20) Therefore, it is seen that during last five years i.e. in comparison to 1916-17 number of students decreased by more than 300 in "Zenana Education" and the same trend was observed in case of the number of teachers. Under these circumstances, demand was raised to reform the system of "Zenana Education" and from a quarter of the Government especially from School Inspectors, a proposal came to stop this arrangement. As a result the Government started to consider abolishing this system gradually without further spreading it (PIB, 1924, pp.15-16 \& 1925, p.23). In the meantime new consideration came for an alternative to "Zenana Education". Mr. West, the Principal of Dhaka Training College played a pivotal role in this regard. $\mathrm{He}$ proposed to impart education by establishing few selected centres for the interested students instead of going house to house and establishing huge number of centres. In those centres reading, writing, Math, Health Education etc shall be included in the course of study for the females. This proposal of Mr. West was originated from the proposal of National Parents Union of England. Mr. West discussed his proposed planning with the Head Teacher of Training School attached to Eden College and Zenana teachers of Dhaka. On getting consent from all in favour of the proposal, the Government accepted the plan and success was achieved primarily (PIB, 1926, p.23, 34, 69 ). On the other hand during the $30^{\text {s }}$, female education of Bengal advanced in contrast with previous years and the interest of female to go to School was increased; when the

\footnotetext{
${ }^{13}$ Report on the Progress of Education in the Presidency \& Burdwan Division 1917, Calcutta: Bengal Secretariat Book Depot, 1918, p.8. Report on Public Instruction in Bengal 1920-21, p. 15. Seventh Quinquennial Review of Progress Education in Bengal 1922-1923 to 1926-27, Calcutta: Bengal Secretariat Book Depot, 1928, p.69. Quinquennial Report on Female Education for the Dacca Circle, Comprising the Dacca, Rajshahi \& Chittagong Division, 1917-18 to 1921-22, Calcutta: Bengal Secretariat Book Depot, 1922, p.1,9.
} 
Government paid importance to institutional education. In some places even the married women become interested to go to School (PEB, 1933, p.74). Besides this, in the year 1930, when Child marriage was banned by law the scope of institutional higher study was increased for the girls. Finally the Bengal Government completely abolished "Zenana Education" in the year 1933 due to various reasons such as want of competent teachers and increase of scope for institutional education that reduced the necessity of this education and the recommendation from lady School Inspectors (PIB, 1934, pp.3031 ). At this time only 551 women were studying under 14 lady teachers in "Zenana Education" education system. In these statistics the worst picture of "Zenana" education was reflected, which was the main reason to cancel this system. But the Government decided that the money which was supposed to be allocated to "Zenana" education would be spent for Muslim female education (PIB, 1934 p.31).

\section{Conclusion}

Finally it can be said that "Zenana" system was an exceptional and alternative concept education system from institutional instruction which prevailed for a long time to extend female education in Bengal. It is notable that there was no male teacher for Zenana education system. Although this education system was in the inner portion of the houses, it had a prescribed curriculum, class, examination and prizes, which were not included in general home education in Bengal.

In the Muslim Society of Bengal, introduction of "Zenana" education was initiated at the moment when the institutional education of the female society was critically poor. It is known from the statement of Indian Education Commission that in the year 1882, the rate of Muslim female literacy was only $8.9 \%$ and $1.1 \%$ in primary and secondary education respectively (IEC, 1882, p31). One cause for the backwardness of women was purdah system, and different superstitions to education were liable for poverty of the society. In this context, the introduction of Zenana education system by Dhaka Muslim Surhid Sammiloni in 1883 was an epoch-making effort for the education of the backward females of the Muslim society in Bengal. While there was no positive environment of institutional education for women and also no more scope of home education for female just at that time, Zenana education was the only hope for them. Though the initiative of Surhid Sammiloni and that of other non-Government organizations was limited, later, the Government's initiative attracted a notable figure of the females to the Zenana education system. It is true that Muslim females having Zenana Education were small in number, but compared to the number of Muslim students having institutional education, the number of Zenana students was not so small. For example, in the statistics of 1917 it is noted that the progress of Muslim female of Bengal in primary education was enough (48.5\%). But in secondary education only 241 (2.8\%) Muslim students were engaged in study (PEB-1912-16, pp.70-71). The purdah system and Child marriage were the main causes behind it. At the age of 12 the females were supposed to stop institutional education and they used to live in the inner part of the houses. So, we have noted that in the year 1917, there were 598 Zenana students in three divisions (Dhaka, Rajshahi and Chittagong) of East Bengal where Muslims are the majority. From this point of view it can be said that the confined Muslim family was interested in "Zenana Education", may be for the time being. 
But Government abolished Zenana education system mostly for the progress of institutional education and also for political unrest in Bengal and India. Besides, the lacking of skill female teacher, different barrier situation of teaching environment for lady teacher, transportation and communication problems were main obstacles for the spread of Zenana education system. In addition, government was hopeful, may be, that Muslim women will pay attention to institutional education instead of Zenana system due to changing situation in the country. But this system of female education was more appropriate for Hindu Society in Bengal. As the purdah system came to an end to a certain extent in the Hindu middle class in the 1 st quarter of the $20^{\text {th }}$ Century, their females became interested in institutional education. On the other hand, during the subsequent years, purdah system and Child Marriage were still there in the Muslim society. Especially in the tenth five years education statement (1937-1942) of the Government, purdah system was marked as one of the major obstacles in education of the Muslim females (PEB, 1944, p.74). The Government should have continued this education system for some more time for the conservative Muslim Society. Unfortunately, due to abolition of "Zenana Education System", the Muslim women who were interested in this system were deprived of this chance of education.

\section{Reference}

"Tripura Anthapur Sthrisikhsa Sabhar Barshik Karzabiboran1278 (Benagli)" (The Annual Meeting of the Proceedings of Zenana Women Education in Teppara, ZWE, 1291), Comilla, 1291(Bengali), Roy, Binoy B. Sthrisikhsa(Women Education), pp. 8287.

Abul Kaium, M. (1348). 'Dhaka Mussalman Surhid Sammilani' (Dhaka Muahammadan Friends Association), Sahithik, 1400, Spring Edition, pp. 20-21.

Amitab Mukharjee, Reform and Regeneration in Bengal 1774-1823, Calcutta: Rabindara Bharati University, 1968, p.15. Tapati Basu, 'Bangali Meyeder Lekhapara',(Education of BengaliWomen\}, Sharadio Anandabazar Patrika, Calcutta, 1398, p. 228.

Annual Report on the Progress of Female Education in the Dacca (PFED), Rajshahi \& Chittagong Division, 1918-19, Calcutta: Bengal Secretariat Book Depot, 1920, p.10. Annual Report on the Progress of Female Education in the Dacca, Rajshahi \& Chittagong Division, 1919-20, Calcutta: Bengal Secretariat Book Depot, 1921, pp.1011.

Calcutta Christian Observer, March, 1849, pp.118-120.

Calcutta University Commission (CUC), 1917-19 Vol. 1, Calcutta: Superintendent Government Printing, 1920, pp.166-168, Vol. 3, pp.365-69.

Census of India 1901, (1902). Volume VIA, Lower Provinces of Bengal, Part II, The Imperial Tables, Calcutta: Bengal Secretariat Press, p.61. 
Dhaka Mussalman Surhid Sammilanir 1886-87 Shaler Anustanpahtra (The Annual Proceedings of Dhaka Muahammadan Friends Association DMFA, 1886-87), Dhaka 1888 , p.16.

Dhaka Mussalman Surhid Sammilanir 1886-87 Shaler Anustanpahtra (The Annual Proceedings of Dhaka Muahammadan Friends Association, DMFA, 1886-87), pp.9-10.

Dhaka Mussalman Surhid Sammilanir Pratham Barshik Karzaybiboron 1883 (The First Annual Proceedings of Dhaka Muhammadan Friends Association DMFA, 1883) pp.5-6.

Dhaka Mussalman Surhid Sammilanir Pratham Barshik Karzaybiboron 1883 (The First Annual Proceedings of Dhaka Muhammadan Friends Association, DMFA, 1883) Dhaka, 1884, pp. 11-18.

Dhaka Mussalman Surid Sammilanir Pratham Barshik Karzaybiboron 1883 (The First Annual Proceedings of Dhaka Muhammadan Friends Association, DMFA, 1883) Dhaka, 1884, pp. 1-14.

Duff, Alexandra, (1855). "Native Female Education”, Calcutta Review, Vol. 25, 1855, pp.98-101.

Eight Quinquennial Review on the Progress of Education in Bengal (PEB) 1927-28 to 1931-32, Calcutta: Bengal Secretariat Book Depot, 1933, p. 74.

General Report on Public Instruction in Bengal (GRPIB) 1896-96, Calcutta Bengal Secretariat Press, 1896, pp. 90-130.

General Report on Public Instruction in Bengal (GRPIB) 1896-96, Calcutta: Bengal Secretariat Press, 1904, p. 36. Progress of Education in Bengal 1902-03 to 1906 pp.12427.

General Report on Public Instruction in Bengal (GRPIB) 1907-1908, Calcutta, 1908, pp. 31, 35. Progress of Education in Bengal (GDEP) 1907-08 to 1911-12, Fourth Quinquennial Review, Calcutta: Bengal Secretariat Book Depot. 1908, pp.124-127.

General Report on Public Instruction in Bengal (GRPIB)1905-1906, p.35.

General Report on Public Instruction in Bengal 1905-06, Calcutta: Bengal Secretariat Book Depot, 1906, p.35.

Ghosh, B. (2000). Banglar Vidhyat Samaj, $4^{\text {th }}$ edition, Calcutta: Prakas Bhavan, 2000, pp.25-26.

Ghosh, Binoy (ed.), Samayikpatrey Banglar Samajcitra(The Social Prospects of Bengal in Periodical),Vol.IV, Calcuta:Vanghyio Sahithaya Parisad,1966,pp.523-525,578-580.

Government Bengal: General Department, Education, Proceedings (GDEP) no.37-38, File no, 10E- 5-6, September 1904.

Government of Bengal: General Department, Education (GDEP), Proceedings no.1, File no, IE- 1.1, June 1915 
Government of Bengal: General Department, Education, Proceedings (GDEP) no. 6-10, File no. IE-10, September, 1907.

Ibid. Report on Public Instruction in Bengal 1932-33, Calcutta: Bengal Government Press, 1934, pp. 30-31.

Long J. (n.d.). Adam's Reports, pp. 132-133.

M. A. Laird, Missionaries and Education in Bengal, London: Clarendon Press, 1972, p. 134. Gaur Mahan Biddalanker, Sthrisikhsa Bidayalk (Enacting of the Women), Edited by Brogendranath Bandopaddhay, Calcutta: Ranjan Publishing House, 1344, p. 9. J.A. Richey (ed.), Selections from Educating Records, Part II, Calcutta: Superintendent of Government Printing, 1922, pp. 34-35. Jogesh Chandra Bagal, Beginnings of Modern Education in Bengal: Women's Education (Mainly Based on Contemporary Records), Calcutta: Ranjan Publishing House, pp. 36-51.

Maleka Begum, Syed Azizul Haque, Ame Nari: Tinsha Bacharer Bangali Narir Itihas(I am Women: The History of Bengali Women of Three Hundred Years), Dhaka:UPL,2001, p.35.

Manindranath Roy, Bangladesher Balika O Anthapurikader Modhay Sikhsa,(Bangladeshi Girl's and Education in Zenana sector), Bharatbarsha, Eleventh Years, Vol. 1, Ashar, 1330, p.82.

Maya, Bhattacharjee, (26 ${ }^{\text {th }}$ Year,). 'Satobarshaw Purbe Muslim Anthapurbasinider Biddaycharcha', Bengal Academy Patrika, Shraban -Assyhin, pp. 44-45.

Mihir \& Sudhakar, 23 Magh, 1309 (1977). 'Mussalman Sthri Samaje Engreji Sikhsa',(The English Education in Muslim Women Society); Mustafa Nurul Islam, Samayikpatrey Jiban O Janamat 1901-1930 (Life \& Popular Verdict in Periodical 19011930), Dhaka: Bangla Academy, 1977, p. 22.

Mohar Ali, M. (1965). The Bengali Reaction to Christian Missionary Activities (18331857), Chittagong: Mehrab Publication, p.5.

Mohar Ali, Missionary Activities, pp. 3-4, 30-32. Rahim, M.A., The Muslim Society and Politics in Bengal 1757-1947, Dacca: The University of Dacca, 1978, p.122.

Molla, M.K.U. (1981). The New Province of Eastern in Bengal and Assam, Rajshahi: University of Rajshahi, pp.210-211.

Murshid, G. (1938). Reluctant Debutante: Response of Bengali women to Modernization,1849-1905,University of Rajshahi : Sahithay Samsad, pp.30-32; Sonia Nisat Amin, Muslim Women, p. 145. Jogesh Chandra Bengal, Banglar Sthrisikhsa (The Women Education of Bengal), Calcutta: Vishawbharati Granthalaya, pp. 27-29.

Proceedings of the Female Education Committee, Eastern Bengal and Assam (FECEBA), 1911, Calcutta: Bengal Secretariat Press 1911, p.96-97.

Progress Education in Bengal (PEB) 1912-13 to 1916-17, pp.110-111. 
Progress of Education in Bengal (PEB) 1902-03 to 1906-07, pp.127-28

Progress of Education in Bengal 1902-03 to 1906-07, Third Quinquennial Review, Bengal Secretariat Book Depot, 1908, p.128.

Quinquennial Report on the Progress of the Education in the Dacca (QRPED), Rajshahi \& Chittagong Division, 1912-13 to 1916-17, Calcutta: Bengal Secretariat Book Depot, 1918, pp.11-12. Annual Report on the Progress of Female Education in the Dacca, Rajshahi \& Chittagong Division, 1917-18, Calcutta: Bengal Secretariat Book Depot, 1918, pp.11-12.

Report on Indian Education Commission (IEC) 1882, Appendix, pp. xlii, xlv, liv.

Report on Public Instruction in Bengal (GRPIB) 1909-1910, Calcutta: Bengal Secretariat Book Depot, 1910, p.38.

Report on Public Instruction in Bengal (PIB) 1912-13, Calcutta: Bengal Secretariat Book Depot, 1914, pp.21.

Report on Public Instruction in Bengal (PIB) 1912-13, p. 21.

Report on Public Instruction in Bengal (PIB) 1914-15, p.15. Report on Public Instruction in Bengal 1917-18, Calcutta: Bengal Secretariat Book Depot, 1919, p.14.

Report on Public Instruction in Bengal (PIB) 1915-16, Calcutta: Bengal Secretariat Book Depot, 1916, p. 16. Report on Public Instruction in Bengal 1920-21, Calcutta: Bengal Secretariat Book Depot, 1922, p. 15.

Report on Public Instruction in Bengal (PIB) 1922-23, Calcutta: Bengal Secretariat Book Depot, 1924, pp.15-16. Report on Public Instruction in Bengal (PIB) 1923-24, Calcutta: Bengal Secretariat Book Depot, 1925, p.23.

Report on Public Instruction in Bengal (PIB) 1923-24, p.23. Report on Public Instruction in Bengal 1924-25, Calcutta: Bengal Secretariat Book Depot, 1926, p.34. Seventh Quinquennial Review on the Progress of Education in Bengal 1922-23 to 192627, p.69.

Report on Public Instruction in Bengal 1932-33, p. 31.

Report on Public Instruction in Bengal (GRPIB) 1914-15, Calcutta: Bengal Secretariat Book Depot, 1916, p.14. Progress of Education in Bengal 1912-13 to 1916-17, Fifth Quinquennial Review, Calcutta: Bengal Secretariat Book Depot, 1918, pp. 110-11.

Report on the Progress of Education in Eastern Bengal and Assam (PEEBA), 1907-08 to 1911-12, Vol. 1, Calcutta: Bengal Secretariat Book Depot 1913, p. 101. Report on the Progress of Education in Eastern Bengal and Assam, 1901 to 1906-07, Vol. 1 Shillong: The Eastern Bengal and Assam Secretariat Printing Office, 1907, p. 86.

Report on the Progress of Education in Eastern Bengal and Assam(PEEBA), 1907-08 to 1911-12, Vol. 1. p. 101-2 
Report on the Progress of Education in Eastern Bengal and Assam, 1907-08 to 1911-12, Vol. 1 p. 102.

Report on the Progress of Education in the Presidency \& Burdwan Division (EPBD) 1918, Calcutta: Bengal Secretariat Book Depot, 1929, p. 9. Report on the Progress of Education in the Presidency \& Burdwan Division (PEP \& BD) 1919, Calcutta: Bengal Secretariat Book Depot, 1920, p.14-15.

Report on the Progress of Education in the Presidency \& Burdwan for the Quinquennium Ending (PEP \& B) $31^{\text {st }}$ March 1917, Calcutta: Bengal Secretariat Book Depot, 1918, p. 8-9.

Roy, Binoy B. (1998). Anthapurer Sthrisikhsa,(The Women Education Zenana Sector), Calcutta : Naya Uddugh, 1998, p. 27.

Roy, Binoy Bushan, (n.d.). Sthrisikhsa, pp. 33-34.

Roy, Gaurogubindha, (1938). Acharzaya Kesobchandra Sen, Vol.I, Calcuta,1938, p.175.

Sonia Nishat Amin, The World of Muslim Women in Colonial Bengal 1876-1940, Leiden: Brill, 1996, p.107.

Sundari, Mohan Das, (1388). Srihatta Sammilanir Zanmakatha (The Birthword of the Sylhet Association), Srihatta,1936, pp. 1-2.

Supplement to the Progress Education in Bengal (PEB) 1912-13 to 1916-17 (Fifth Quinquennial Review), Calcutta: Bengal Secretariat Book Depot, 1914, p.21.

Supplement to the Progress Education in Bengal (PEB) 1912-13 to 1916-17, p. 20. Supplement to the Progress Education in Bengal 1917-18 to 1921-22, (Sixth Quinquennial Review), Calcutta: Bengal Secretariat Book Depot, 1920, p.20.

Supplement to the Progress Education in Bengal (PEB) 1912-13 to 1916-17, pp. 70-71.

Supplement to the Report on Public Instruction in Bengal (GRPIB) 1910-1911, Calcutta: Bengal Secretariat Book Depot, 1911, p.17.

Tenth Quinquennial Review on the Progress of Education in Bengal 1937-38 to 194142, Alipore: Bengal Government Press, 1944, p.74.

The English Annual Report of the Uttarpara Hitakari Sabha (EARUHS) for the year 1870-71, Uttarpara, 1872,p. 12.

Yousufjee, Nousher A.K. (1890). Banglar Mussalman (Muslims of Bengal), Calcutta Shahansha \& Co. pp. 43-44. 